ADDIN, Volume 11, Number 2, August 2017

\title{
THE FACE OF ISLAMIC CIVILIZATION IN INDONESIA
}

\author{
Adri Efferi \\ STAIN Kudus, Central Java, Indonesia \\ adri.efferi@gmail.com
}

\begin{abstract}
Islam is a source of civilization for its adherents, in accordance with the conception of the word civilization itself, which means the product of buman life activity, whether in the field of politics, economy, social, education and so forth. So Islam as a religion, in its scriptures also gives clues about the things that are needed in human life, although it is not in the language of detailly. Enforcing the application of Arabic Islamic Shari'a into the society such as Indonesia, of course it will create feelings of alienation in religion. As an example is in the case of hijab for muslim woman (muslimah). Arabic or Middle Eastern dress models and veils are dark colors. If these models are used in Indonesian Moslem society, the wearer will look different and become strange in that society. Therefore it is needed to take a wise attitude in implementation the teaching of religion, so that it will be suitable with local culture that is already exists.
\end{abstract}

Keywords: Islamic Civilization, Local Culture, Indonesian Islamic Model. 


\section{Abstrak}

WAJAH PERADABAN ISLAM DI INDONESIA. Islam adalah sumber peradaban bagi para pemeluknya, sesuai dengan konsepsi peradaban kata itu sendiri, yang berarti produk kegiatan kehidupan manusia, baik di bidang politik, ekonomi, sosial, pendidikan dan sebagainya. Jadi, Islam sebagai agama, dalam kitab Injil juga menunjukkean tentang hal-hal yang dibutubkan dalam kehidupan manusia, meskipun tidak dalam bahasa secara detail. Penegakan penerapan syariah Islam dengan nuansa bahasa Arab, dalam masyarakat non Arab seperti Indonesia akan menciptakan perasaan keterasingan dalam agama. Seperti contobnya dalam kasus jilbab bagi wanita muslimah. Model Arab atau Timur Tengah yaitu warna gelap dan memakai jilbab. Jika model ini digunakan di tengah masyarakat muslim Indonesia, pasti pemakainya akan terlihat berbeda dan menjadi asing dalam masyarakat tersebut. Oleh karena itu diperlukan sikap bijak dalam menerapkan ajaran agama terutama agar sesuai dengan budaya lokal yang sudah ada.

Kata Kunci: Peradaban Islam, Budaya Lokal, Model Islam Indonesia.

\section{A. Introduction}

Indonesia is not a country based on Islam but Islamic civilization dominates the life of the nation of Indonesia, especially the people who are Muslims. The existing of cultures gradually formed an Islamic civilization which is capable of bringing Indonesians into the progress and intelligence. This cannot be separated from the role of Muslim traders from Arabia, Persia and India as well as locally people themselves who take part actively in the spread of Islam in Indonesia

It is important to be known that the area of Indonesia which was formerly named as the Nusantara is known as a fertile country and rich of natural potential. Therefore, it is not surprising that foreign traders came to the regions of the archipelago. By the development of trade among the nations, 
it also causes the development of ports, especially in the coastal areas of island. The advancement of the international trade caused the kingdoms in the archipelago become rich and prosperous, the existing ports or ports grew. This caused more traders from various nations to arrive conducting trade transactions with local people in the archipelago. Then it will make interaction between local society and foreigners including the Moslem trader. So that it also influences the local culture.

Talking about civilizations is very interesting, because it became part of a significant human life. Human history was filled with many different civilizations, depending on the rulers and the leaders of the world. Those who are strong will determine the model of human civilization. Especially in this global era, the model of civilization is almost uniform because the territorial, national, cultural, religious, and racial barriers are not able to fortify themself from efforts to market a model of civilization that becomes a trend in the strong and powerful side. So at its turn, the cultural, religious, national, and racial features become faded and eventually destroyed, then replaced by a worldwide model of civilizatition.

The interpretation of the word civilization is often associated with culture, even many western writers equate or identify the term Islamic culture with Islamic civilization. In fact, it is not uncommon for Islamic civilization to be associated with Arabic civilization, although in fact between Arabic and Islam such as a coin that is inseparable but it still can be differed.

The changes which occur on Arab culture or civilization started by the arrival of Islam brought by a prophet named Muhammad SAW. In this period Islam as a religion or belief developed into a civilization that blends with the Arabic, even it developed rapidly into half of another world. 
Islam is not only a perfect religion but also a source of civilization for its adherents. Because it is accordance with the conception of the word civilization itself, which means the product of human life activities, both in the politic, economic, social, education and so much else. Islam as a religion, in its scriptures also gives clues about the things that are needed in human life, although it is not admitted in detail language.

Furthermore, related to the tide and downs of Islamic civilization and culture, according to Harun Nasution the history records that Islam had been glorious and progress in all areas for hundreds of years until making the Islamic community feel proud of the triumph once achieved. On the other hand, Muslims also ever have experienced of setbacks and backwardness. Therefore, Muslims arise the view that the political and Islamic civilization is an integral part of teaching Islam. The reason is that Islamic teachings have high flexibility and elasticity, and have a strong relevance to the development of Muslims themselves. ${ }^{1}$

A case that can be an example is the growth and development of Islam in Indonesia. History has witnessed that Indonesian Muslims have a very big role to the struggle for independence for the Indonesian nation itself. Although it must be admited in the next relationship, it also ever happen frictions. As stated by Slamet Muljana that at the time of independence has been achieved, on August 17, 1945 arose the flaming among the society who wanted to determine the ideology of the nation state of Indonesia. The upheaval was divided into two camps, Muslims and Nationalists. One of them wanted to make the State of Indonesia as an Islamic State, but it challenged from other people who wanted to

${ }^{1}$ Harun Nasution, Teologi Islam: Aliran-aliran, Sejarah, Analisa Perbandingan, (Jakarta: UI-Press, 1986), 12-14. 
make the State of Islam to be a Pancasila (the five basic principles of the Republic of Indonesia) State. As a result of the upheaval of the development of Islam in terms of political increasingly enlarged, due to the disappointment of the Muslims who want to make the State of Indonesia into Islamic caliphate, and the disappointment peaked then declared the State of Indonesia as a State of Pancasila. ${ }^{2}$

Apart from those upheavals above, the essence of the arrival and spread of Islam in Indonesia is more dominated by peaceful ways. Among them are trades led by Arab merchants, marriage, education, art and culture. This condition is certainly very different from the process of spread of Islam in other regions of the earth and the average cannot be separated from the action of war. So it is not wrong if the West (oriental) said that Islam is very familiar with sword or violence.

Based on some explanations above, it becomes the reason that this paper needs to be presented in front of the readers as well. The author wants to give a brief description although it has not been fully yet, related to Islamic civilization generally with Islamic civilization that developed in Indonesia. Although both of them have similarities in many ways, but each other is not fully same, it means that there is still a gap that can be shown to distinguish it.

\section{B. Discussion}

\section{The Nature of Islamic Civilization}

Since 14 centuries the rise of Islam also has colored the history of world civilization. In fact, the rapid development of Islam, both in the west and east, in the eighth century to

${ }^{2}$ Slamet Muljana, Kesadaran Nasional: dari Kolonialisme sampai Kemerdekaan, (Jakarta: LKiS, 2008), 7. 
$13 \mathrm{AD}$ able to master the various civilizations that existed before. It does not matter that if the Islamic civilization is considered as one of the greatest civilization of influence in the world. In fact, until now, various types of Islamic civilization that can still be witnessed in a number of former states of former Islamic rule, such as Baghdad (Iraq), Andalusia (Spain), Fatimid (Egypt), Ottoman (Turkey), Damascus, Kufah, Syria.

The basic assumption can be built that civilization comes from the word adab which in this sense contains the sense of etiquette, behavior or manners. Thus civilization is all manner of manners and manners, which is realized by Muslims from time to time in both politic, economic, education and other social realities.

The language of Islamic civilization is the transfer of the language of the Arabic vocabulary: al-khadlarah al-Islamiyah, al-madaniyah al Islamiyah or al-tsaqofah al Islamiyah, often translated with Islamic culture. ${ }^{3}$ Meanwhile in English there are also two different expressions of culture and civilization. However, in fact, in its use tend to be good that among many Indonesian, Arabic and Western people still find the synonim between the vocabulary of civilization and culture.

On the other hand, from the root of the word madana, then the birth of the noun of tamaddun which literally means civilization which can also mean city based culture or cultural city. According to Abdullah although he is not very convinced, that among Arabian writers the word of tamaddun was used for the first time by Jurji Zaydan in a book titled Tarikh al-Tamaddun al-Islami (History of Islamic Civilization),

${ }^{3}$ Ahmad Syalaby, Mausu'ah at-Tarikh al-Islami wa al-Hadharah al-Islamiyah, (Kairo; t.tp., 1969), 10. 
published in 1902-1906. Furthermore, since then, the term tamaddun is widely used among Muslims. ${ }^{4}$

Regardless of the various meanings and diversity in the use of the term, according to al-Attas that Islam is revealed as a religion (dien), actually had the concept of civilization. Because the word of dien itself has brought meaning of sorrow, the composition of power, the structure of law and human tendency to form a society that obeys the law and seeks a just government. It means that in the term of dien is hidden a system of life. Therefore when the religion of Allah named Islam has been perfected and implemented in a place, then the place was given the name of Medina (formerly the city better known as Yathrib). ${ }^{5}$ Furthermore, according to Ibnu Mandzur from the root word of dien and Medina is then formed a new root of madana, which means to build, establish the city, promote, purify and prestiged. ${ }^{6}$

According to the prominent Muslim historical figure Ibn Khaldun, the sign of civilization is the development of science such as physics, chemistry, geometry, arithmetic, astronomy, optics, medicine and so on. Even according to him the advancement of a civilization is very dependent or related to the advancement of science. So the most important substance of civilization in Ibn Khaldun's theory is science. Science cannot exist without the communities who actively develop it. Therefore a civilization must start from a small community and when the community gets bigger, it will create a great civilization. The community usually appears in urban areas or even in a city. From the city that will form a

${ }^{4}$ M. Amin Abdullah, Falsafah Kalam di Era Postmodernisme, (Yogyakarta: Pustaka Pelajar, 2004), vii-ix.

${ }^{5}$ Syed Muhammad Naquib al-Attas, "Islam, Religion, and Morality", in Prolegomena to the Metaphysics of Islam, (Malaysia: ISTAC, 1995), 43-44.

${ }^{6}$ Ibnu Mandzur, Lisan al-'Arab, (Mesir: Dar al-Hadis, 1988), volume 13, 402. 
society that has a variety of life activities that emerged from a community system and eventually born a State. The city of Medina, the city of Cordova, the city of Baghdad, the city of Samara, the city of Cairo and others are a few examples of the city coming from the community that later gave birth to the State.

As an addition in what Ibn Khaldun has said, as quoted by Muhammad Abdul Jabbar Beg, behind the factor of activity and creativity of society as the support of a civilization, there are still other factors of religion, spirituality or belief. Contemporary Muslim scholars generally accept the notion that religion is the principle of civilization, rejecting that religion is barbarity. Sayyid Qutb states that faith is the source of civilization. Although the organizational structure and material form in the Islamic civilization is differ, but its principles and values are one and permanent. Those principles are devotion to God (taqwa), belief in the unity of God (tauhid), supremacy of humanity above all material things, the development of human values and guarding of animal desires, respect for the family, realizing its function as the caliph of Allah on the earth according to His instructions and commandments (shari'a). ${ }^{7}$

Still quoting from the same source, in line with Sayyid Qutb's opinion, Sheikh Muhammad Abduh stressed that religion or belief is the principle of all civilizations. Ancient nations such as Greece, Egypt, India and others, built their civilization from a religion, belief or conviction. Arnold Tonybee also acknowledged that spiritual power (batiniyah) is the power that enables a person to produce outward manifestation which is then called as civilization.

${ }^{7}$ Muhammad Abdul Jabbar Beg, in The Muslim World League Journal, November-December 1983, 38-42. 
If religion or belief is a principle of civilization, and if religion and belief form a person's perspective on something which in turn can affect its actual action or outward manifestation, it will be in line with modern theory that the worldview is a principle for every civilization of the world.

In a paper presented by Hamid Fahmy Zarkasyi, he mentioned that civilizers, philosophy, science and religion scholars are now using the worldview as a matrix or framework. Smart Ninian uses it to study religion, S.M. Naquib al-Attas, al-Mawdudi, Sayyid Qutb, used it to explain the concept building in Islam, Alparslan Acikgence to study science, Atif Zayn, used it for ideological comparison, Thomas F Wall for philosophical study, Thomas S Kuhn with the paradigm concept is actually the same as using worldview for science study. Although they differ on the meaning of the worldview, they generally associate worldview with civilization or all of one's personal, social, and religious activities. ${ }^{8}$

Thus, as with other civilizations, the substance of Islamic civilization is the subject of Islamic teachings that is not limited to the belief system, the mindset and the values, but a super-system that encompasses the whole view of being, especially the view of God. Therefore theology (aqidab) in Islam is the foundation for the mindset, values and all activities of Muslim life. That is the life view of Islam, if the view of life accumulates in one's mind, it will radiate in the whole life activity and will produce work ethic and manifested in the form of real work. And if it radiates from the minds of society or nation then it will produce the philosophy of life of nation and system of life of the nation. So the substance of Islamic civilization is the view of

${ }^{8}$ Hamid Fahmy Zarkasyi, "Membangun Peradaban Islam Kembali", in Workshop Pemikiran Ideologis Forum Ukhuwwah Islamiyah Daerah Istimewa Yogyakarta, April 15, 2007, 5. 
Islamic life. But the most important aspect of life is thought and trust.

\section{Islamic Civilization or Arabic Civilization}

Basically religions and traditions are two different worlds and each of them has its own independence. Indeed, sometimes the areas of tradition and religion overlap, on the one hand, the territory of religion comes from "the normative of revelation" and tradition comes from "manmade", hence the tradition tends to change according to the development of time and the changing times. Well, this allows for the assimilation of religious behavior in everyday life that is adapted to the prevailing tradition.

There are many things that we should consider in terms of positioning the nash with a growing culture or tradition. However, there must be a reconciliation between God's revelation by considering cultural, and contextual, factors. This is what will be required of Islamic through the process of turning enterprises over to the indigennous people which borrows the term by Gus Dur. In addition to the social order of cultural societies intersect with religious behavior, especially those dealing with Jurisprudence.

Many authors identify the culture and civilization of Islam with Arabic culture and civilization. That opinion may be justified even though the truth between Arabic and Islamic remains indistinguishable. In the classical period of the central government only one and the role of Arab in that is very dominant. All Islamic domains use the Arabic language. All the cultural expressions expressed through the Arabic language. Although at that time the non-Arab nations also have started to participate in fostering a culture and civilization, especially non-Muslims also contribute a lot of cultural work. 
Lately there is a kind of movement that is quite massive and radical, with the tendency of a number of parties who put forward the construction of Islamic shari'a in the Arabic face while denying the reality of other traditions. Although admittedly there is nothing wrong with using Arab culture in expressing one's religiousness, provided that it does not give rise to a conflict in a society framed in solid conceptual understanding.

But the problem is when the use of the assumption that Arabic color is a single form of religious that is considered the most valid and absolute. So the law must be applied to all conditions and situations patently. It certainly affects the circumstances in which Arabic expression becomes dominant, even hegemony of culture and tradition that developed in local communities. What is more disturbing the emergence of justifications such as not perfect, misguided, heretical or idolatrous to those who do not use the Arabic expression? About the use of Hijab or veil for example, as people who wear headscarves view that women who have not been wearing the veil or veil is different from the bijab commonly used in Arabic, it means that Islam is not Kaffah.

The phenomenon is part of a variety of phenomena that describe the conflict and tension between Islamic law and culture. There is one issue that arises whether the culture that develops in society must be subject to the expression of Islamic law in the Arabic style as above.

Thus the truth of Islam has been expressed in various colors and shades of expression in line with the inevitability of language, culture and customs of its adherents. All expression by following the cultural relativity is legitimate because of no other way anymore. A particular customary pattern-quotes Ibn 'Asyur, a famous mufti Maghrib, as quoted by Nurcholish Madjid, "Speech: Universalism of Religion and Religion of 
Civilization," in M. Dawam Rahardjo, in Encyclopedia of the Qur'an: Social Commentary Based on Concepts Key, said that even if it is the cultural custom where the Prophet Muhammad's birth is Arab custom, it cannot be forced on other people from other regions. Each cultural environment has the right to develop the core of Islamic truth according to local cultural forms of necessity. Each still has a chance to contribute to Islam and its civilization. Likewise with the Muslims of Indonesia, always open wide opportunities to creatively and productively contribute to the development of Islamic culture. ${ }^{9}$

\section{Islamic Civilization Model in Indonesia}

There is an interesting phenomenon and at the same time for some people considered worrisome, related to the thoughts and ways of Muslims in understanding as well as implementing the teachings of Islam. It is said to be interesting, because the thoughts about Islam and all the teachings that are differ in it very much. But on the other hand, it is called worrying because there are also some people who want to return to the back, both in thought and behavior and it is like when the emergence of Islam occured in the early days (Prophet and Companions). According to Karen Armstrong, how the movement to return to the strong text is oriented to the past, in many ways has made Islamic studies become very textual, black and white, barren, unproductive, dry and not rich. ${ }^{10}$

However, this study does not intend to oppose let alone to the area of blame. It is only giving different views

${ }^{9}$ M. Dawam Rahardjo, Ensiklopedi Al-Qur'an: Tafsir Sosial Berdasarkan Konsep-konsep Kunci, (Jakarta: Paramadina, 1996), xxxii-xxxiii.

${ }^{10}$ Karen Armstrong, Berperang Demi Tuhan: Fundamentalisme dalam Islam, Kristen, dan Yabudi, tranls. Satrio Wahono, et. al., (Jakarta: Serambi Ilmu Semesta, 2001), 577. 
on understanding or studying Islam. Due to the extent that the author learned and found in the scriptures, the spaces for the different are actually very wide open. But unfortunately the spaces are not aware of it, even still tend to many who do not like when there is a different, it is actually needed a wisdom.

The existence of wisdom will make us accept (welcomed), a fact that Islam is multi faces. What when Islam intersects with local culture, the immediate thing is the enriching symbiotic process. This phenomenon will occur in any part of the region, not least in Indonesia. Then it arises the various variants of Islam. There are Islam-Javanese, Islam-Madura, Islam-Malay, Islam-Sasak, Islam-Bima, and so on each of which presents different characters from each other. Similarly, not only Islam-Arab, but also Islam-Iran, Islam-China, Islam-American, Islam-Africa, Islam-India, and Islam-Indonesia emerged with their own truth building.

Enforcing the application of Arabic Islamic Sharia into the society such as Indonesia, of course it will create feelings of alienation in religion. As an example is in the case of bijab for muslim woman (muslimab). Arabic or Middle Eastern dress models and veils are dark colors. If these models are used in Indonesian Moslem society, the wearer will look different and become strange in that society. Therefore it is needed to take a wise attitude in implementation the teaching of religion, so that it will be suitable with local culture that is already exists.

In Indonesia, there are very interesting examples of peaceful and accommodating activities of Islam. The movement that has been carried out by a group of guardians (Walisongo) that can be an example; how they unite the religious proselytizing and local tradition without crashing aqidah. Walisongo incorporated the Islamic worldview into traditions that can be affirmed. One form of success of the 
spreaders of Islam in the archipelago is through language. The process of Islam was by incorporating Arab-Islamic terms into the local language. There are many Malay and Indonesian vocabulary that are absorbed from Arabic. The examples is the vocabulary of akal, musyawarah, adil, adab, akblak, dewan, kalimat, khutbah, jama'ah, kursi, zahir, batin, kalbu, kuliah, etc.

The spreading of Islam has been done by the walisongo above, according to Prof. al-Attas as a success that overcomes the Hindu-Buddhist achievement. The reason is that they succeeded in raising the Malay language into a unified language in the archipelago of Nusantara. ${ }^{11}$ The facts show that the language of the Sanskrit Hindus was unpopular except among the palace and their religious leaders alone. While the Malay language that has absorbed the Arab-Islamic term is more popular and the area of spread is wide along with the extent of Islamic propagation in the archipelago.

In addition, there were various phrases in Malay or Indonesian derived from Arabic vocabulary which it is also known type of Javanese Arabic script which is often called Pegon writing. Its writing is read Javanese or Sundanese but the letters are written in Arabic script. This type of writing is popular in traditional Pesantren (Islamic school for children and young people whom are boarders) which has been taught for hundreds of years, since the coming of Islam. However, unfortunately this type of writing is no longer popular in Indonesia except among Pesantren. This type of writing is the uniqueness of Muslims in the archipelago inheritance of previous Islamic propagators.

The clothes of Muslims in Indonesia also have its own characteristics. They wear gloves, shirts and national songkok

${ }^{11}$ Syed Muhammad Naquib al-Attas, Historical Fact and Fiction, (Malaysia: UTM Pres, 2011), xvi. 
(male Muslim cap made from velvet). The piety cloth (baju taqwa) which is similar to Arab-style shirt is cut to the waist. It is said that the name of this piety is derived from the taqwa vocabulary in the Qur'an, which is commonly used to name people who have a noble personality. It is as well as blangkon (Javanese cap for male) which mentionly cannot be separated from the Arab-Islamic symbol that is a model of the imam's turban, which is a long cloth wrapped around the head in a certain way. In Javanese land, the imam's turban was practically made that is the coil was attached so it could easily be removed and used again. Because in Java, then the cloth using batik. So we can notice that the imam's turban which is commonly used by mufti of Yemen Hadramaut or habib in Indonesia looks almost similar to blankon. The proselytizer of Yemen is widely spread in Indonesia. They introduce Islamic traditions to the Muslim community of Indonesia.

The symbols and traditions in the archipelago above that prevailed among Muslim Nusantara is a product of Islamization. We can be accurate to mention the Islamic tradition of Islamization. It is not muslim religion whis is archipelagic. Therefore, the influence of Islam is stronger and entrenched and even contains philosophy based on al-Qur'an and hadith. After the islamization the thing that can be seen is the color of Islam is not the color of HinduBuddha or animism-dynamism. The resultis that from the fifteenth to the seventeenth century on the earth of the archipelago saw a change of thought in his worldview which gave rise to philosophers, scholars and international thinkers with weighty works. Syed Muhammad Naquib al-Attas says: The first translation of the Qur'an in Malay has been held including its edition based on al-Baydawi, other translations and its edition and original works in the field of philosophy, 
mysticism and theology of kalam which also have been held in this day. ${ }^{12}$

So, the way that has been done Walisongo should be continued especially for their proselytism and struggle. Their proteism included the values of Taubid into Indonesian Muslim traditions, not making Indonesian the meaning of Tauhid.

The fact that Islam came to Indonesia was brought by Sufis which caused Islam in the early Islam compromising with local culture. The encounter of Islam with local culture is often misunderstood as the cause of the lack of purity of Indonesian Islam. However, it should be emphasized that Sufism which developed in Indonesia is Sufism combined with shari'a in a balanced way. ${ }^{13}$ So the Tarekat (Islam for mystics to follow, especially Sufism) which grows is Tarekat which is in line with that view, such as the Qadiriyah, Naqshabandiyah and Syattariyah congregations. This Tarekat is considered respected because it has a continuous pedigree to Prophet Muhammad SAW and the content is not contrary to the Shari'a.

Some of the characteristics of Sufi Islam can be recognized from the religious expression of Muslims that are still preserved to this day. First is respecting the teachers, both living and dead. This honor gave birth to the tradition of pilgrimage grave to the tomb of the scholars and guardians' thrives among the Muslims of Indonesia. In this pilgrimage the perpetrator recites tablil and tawasul to pray for the soul of the clergy or guardian, as a close and beloved of God, so that they are asked for a prayer to Allah. In addition tawasul,

${ }^{12}$ Syed Muhammad Naquib al-Attas, Islam dalam Sejarah dan Kebudayaan Melayu, (Malaysia: Angkatan Belia Islam, 1990), 45.

${ }^{13}$ Azyumardi Azra, Jaringan Ulama Timur Tengah dan Kepulauan Nusantara Abad XVII dan XVIII, (Bandung: Mizan, 1994), 24. 
the pilgrims also do itibar (taking lessons) on the struggle of the guardian in spreading Islam.

Second, the recitation of shalawat to the prophet is the purest form of tawasul Islam Nusantara. This reading which has been modified in such a way that various kinds of sholawat are born, such as the reading of the Prophet's Mawl, diba', barzanji, shalawat munjizat, manaqib, and others. Syeh Burhanddin Ulakan in Minangkabau (pupil of Sheikh Nur adDin ar-Raniri) creates Sholawat Dulang for the proselytizing means. Similarly Kiai Manshur Shiddiq in East Java to face the atheist group created Shalawat Badr. The reading of this sholawat is done in surau or langgar (smaller prayer house than mosque) every night on Friday or celebration of the birth of Prophet Muhammad. The form of reading is sometimes only in oral form, but there are accompanied by various instruments such as tambourines.

The third is the tradition of reciting the tahlil and the Qur'an when someone dies. In addition to being a means of praying for the deceased Muslims, this tradition is also a means of solace for abandoned families, replacing preIslamic habits that fill death events with gambling and binge drinking. The tradition of lamenting the dead by the Wali (the spreader of Islam in the archipelago) is replaced with talqin, while the habit of gambling is replaced with the recitation of ziker and tablil.

Fourth, the Guardians make creations in da'wah by using various means such as wayang (the shadow play with leather puppets often) art or the utilization of traditional tools such as beduk (drum made from leather which is used in mosque to give the prayer time) and kentongan for Muslim worship purposes. The two means used as a notice and a sign of a meeting or warning sign (depending on the rhythm) are used by the Wali to inform the commencement of prayer 
time, since the call to prayer is not enough communicative given the distance between the mosque, langgar or surau with houses are very remote and dispersed. With the tools of drum and kentongan whose voice can be heard in other villages make it easier to mark the entry of prayer time. Even the length of the beduk and kentongan are aligned with the position of the mosque or surau and langgar. The mosque's beduk is different from the usual mosque. The tool that used to be just a tool, then developed as a determinant of the status of the mosque concerned, and hereafter became the embodiment of Islam in the archipelago, so it is not perfect a mosque that does not have a representative beduk.

The factor that caused Islam to flourish was the deployment of centers of civilization circles in three precise dots, namely palaces, pesantren, and markets. ${ }^{14}$ The palace as a center of power plays a role in the field of politics and the arrangement of social life. Here with the support of clerics who are directly involved in the government bureaucracy, Islamic law is formulated and applied. Here also the book of history is written as the basis of legitimacy for Muslim rulers. Pesantren plays a role in education, and is the second cultural center after the palace. Here the religious teaching networks in the wider community are built, in the city or in the countryside, as well as the themes of the study. Here also the religious books are written and copied for distribution.

The role of pesantren or dayah and meunasab in Aceh, surau in Minangkabau was increasingly prominent in the 18th century AD throughout the archipelago. This formerly regional institution developed into a supra-regional institution whose leadership and learners were no longer based on ethnicity. It grew into a universal institution that accepts

${ }^{14}$ Taufik Abdullah (ed.), Sejarah Umat Islam Indonesia, (Jakarta: Majelis Ulama Indonesia, 1991), 34. 
teachers and students regardless of ethnic background and area of origin. At that time, pesantren or dayah were able to form a network of intellectual leadership and the spread of religion in various levels and between regions. ${ }^{15}$

While the market plays a role in the field of economy and trade. The market is a residential area of merchants, educated people, and other middle classes, including craftsmen, who are dealing directly with the evolving cultural situation. Here people of different ethnicities and different races meet and interact, and exchange ideas about trade, politics, social, and religious issues. Here also the development of Malay language experienced a decisive dynamic for the extent of its spread to various regions of the other archipelago. In the midst of this plural community there are of course mosques where they gather and attend religious studies. Here also Madrasah was established, and religious books were imported from Arab and Persian countries, sent to pesantren to be copied, adapted, or translated in order to be disseminated. Here also devised a strategy of spreading religion following the emporium networks they had built for a long time. Of course, the three center points of this circle of civilizations support each other, and interact with each other. This is reflected in the order of cities built in the age of the empire's empire and emporium of Islam.

The Islamic cities in the archipelago are built following the model of the city in Arabia and Persia. It is different from the cities in the Hindu and the old cities of Europe. The old cities of Europe were built by placing the castle as a separate part of the whole order of city life. Islamic cities place the palace as an integral part of city life. That way, the

${ }^{15}$ Azyumardi Azra, Jaringan Ulama Timur Tengah dan Kepulauan Nusantara Abad XVII \& XVIII: Akar Pembaharuan Islam Indonesia, Jakarta: Kencana Prenada Media Group, 2004), 50. 
palace is not alienated and can interact dynamically with outside civilization centers such as educational institutions and markets. Such a city model allows the palace to influence the city's culture strongly through life in the pesantren and the residential centers of merchants, craftsmen, and intellectuals called markets or bazaars.

Arrangement of such cities and the placement of the three points of the circle of centers of civilization when the Islamization process enters the second stage. That is when the rational and philosophical implications of the concept of monotheism began to be included in conveying the teachings of Islam. And, Islam is not quite formally accepted or based on formal legalistic aspects. If that is emphasized, then Islam will not take root deeply in the soul, mind, and outlook of life of archipelagic people.

These forms of influence include, first, influence in terms of language and names. Indonesian as a language of unity is heavily influenced by Arabic. Arabic has a lot of united in Indonesian vocabulary, for example mandatory word, fardu (obligatory), physical, spiritual, deliberations, letters, news, newspapers, selling, chairs and masks. In terms of names are also widely used names that are characterized by Islam (Arab) such as Muhammad, Abdullah, Anwar, Ahmad, Abdul, Muttalib, Muhaimin, Junaidi, Aminah, Khadija, Maimunah, Rahmillah, Rohani and Rahma.

Second is that the influence of culture, customs and art. Habits that many evolved from Islamic culture can be a greeting, tablilan event, thanksgiving, yasinan and others. In terms of art, many found music art such as kasidah (religious islamic chant in Arabic sung), tambourine, marawis, barzanji and shalawat. We also see the influence in the field of art of architecture houses of worship or mosques in Indonesia 
are mostly influenced by mosque architecture in the Middle East region.

Third is the influence in politics. This influence can be seen in the system of government of the Islamic kingdoms in Indonesia such as the concept of khilafah or sultanate that we often encounter in the kingdoms such as Aceh, Mataram, Demak, Banten and Tidore.

Fourth is the influence in the economic field. Coastal areas are often visited by Islamic traders from Arab, Persian, and Gujarat who apply the concept of buying and selling in Islam. The other obligations are paying rakat (tithe in rice or money paid on the last day of fasting month) or other charity of jariyah, such as alms, infak, waqaf, taking care of orphan and poor people. This makes the Islamic economy growing.

In addition to the above four influences, the forms of the blend of Islamic teaching with local culture can also be seen in the tangible relics of objects. The remains are largely the result of a blend of Islamic culture with local culture. The many forms of the blend of Islamic culture with local culture according to anthropologists as a sign that the spread of Islam in Indonesia in a peaceful way, without any attempt to eliminate the culture that has been there before. This fact also applies in other countries, such as in Egypt and Iraq. The arrival of Islam in these countries does not eliminate the previous relics, even protect and care for them. This is very valuable, because we can still witness the great work of man in the past. The remains of Islamic history in Indonesia are in the form of a mosque (such as the Indrapura Aceh Mosque, Demak, Kudus, Sunan Ampel and others), the palace (like the palace of the Cirebon Kesepuhan), the grave in Arabic letters (like the tomb of Maulana Malik Ibrahim, Islam Talo, Sunan Bayat and others), calligraphy and literary works. 


\section{Conclusion}

Prior to Islam entered and developed in Indonesia, the Indonesian nation had been embraced Hinduism and Buddhism, in addition to the belief in the spirits of their ancestors. In the study of religious sociology, such beliefs are called animism or dynamism. In the next stage, after the Islamic religion into Indonesia, this religion has great influence in various aspects of Indonesian life, whether in the political, social, economic, or in the field of culture or civilization.

Certainly the civilization that resulted from the meeting between Islam and local culture that already exist in Indonesia which will lead to a civilization that is certainly also typical of Indonesia, such as in terms of dressing, associating and the work in physical form. And it is not wise or a mistake to think, if the application of Islamic teachings that adopt some Arabic culture, then must be forced to be implemented also in other parts of the region, which incidentally already has its own culture or civilization.

Finally hopefully this paper can open the horizons of thinking all of us that Islam is identical with Arabic, but not necessarily all that comes from Arabic is in accordance with the teachings of Islam. 


\section{REFERENCE}

Abdullah, M. Amin. Falsafah Kalam di Era Postmodernisme. Yogyakarta: Pustaka Pelajar, 2004.

al-Attas, Syed Muhammad Naquib. Historical Fact and Fiction. Malaysia: UTM Pres, 2011. . Islam dalam Sejarah dan Kebudayaan Melayu. Malaysia: Angkatan Belia Islam, 1990. . "Islam, Religion, and Morality", in Prolegomena to the Metaphysics of Islam. Malaysia: ISTAC, 1995.

Armstrong, Karen. Berperang Demi Tuhan: Fundamentalisme dalam Islam, Kristen, dan Yahudi, tranls. Satrio Wahono, et. al. Jakarta: Serambi Ilmu Semesta, 2001.

Azra, Azyumardi. Jaringan Ulama Timur Tengah dan Kepulauan Nusantara Abad XVII \& XVIII: Akar Pembaharuan Islam Indonesia. Jakarta: Kencana Prenada Media Group, 2004. - Jaringan Ulama, Timur Tengah dan Kepulauan Nusantara Abad XVII dan XVIII. Bandung: Mizan, 1994.

Beg, Muhammad Abdul Jabbar. The Muslim World League Journal, November-December 1983.

Mandzur, Ibnu. Lisan al-'Arab. Mesir: Darul Hadis, 1988.

Muljana, Slamet. Kesadaran Nasional: dari Kolonialisme sampai Kemerdekaan. Jakarta: LKiS, 2008.

Nasution, Harun. Teologi Islam: Aliran-aliran, Sejarah, Analisa Perbandingan. Jakarta: UI-Press, 1986.

Rahardjo, M. Dawam. Ensiklopedi Al-Qur'an: Tafsir Sosial Berdasarkan Konsep-konsep Kunci. Jakarta: Paramadina, 1996. 
Syalaby, Ahmad. Mausu'ah at-Tarikh al-Islami wa al-Hadzarah al-Islamiyah. Kairo: t.tp., 1969.

Taufik Abdullah (ed.). Sejarah Umat Islam Indonesia. Jakarta: Majelis Ulama Indonesia, 1991.

Zarkasyi, Hamid Fahmy. "Membangun Peradaban Islam Kembali", in Workshop Pemikiran Ideologis Forum Ukhuwwah Islamiyah Daerah Istimewa Yogyakarta, April 15, 2007. 